\title{
Does an External Governance Framework Enhance the Performance of Pakistan's Banking Sectors? Foreign Ownership as Moderator
}

\section{Shoaib Ali ${ }^{\rtimes}$ \\ Hafiz Muhammad Naveed ${ }^{2}$ Abubakar Khaliq ${ }^{3}$}

'School of Management, Jiangsu University, Zhenjiang, China.

Email:Shooaibali6@gmail.com Tel: +8618651289296

${ }^{2}$ School of Finance and Economics, Jiangsu University, Zhenjiang, Jiangsu Province, China

Email:Hafiznaveed778@gmail.comTel:+8618651289309

${ }^{3}$ Hailey College of Commerce, University of the Punjab, Lahore, Pakistan.

Email:abubakarkhaliq58@gmal.com Tel: +923043554313

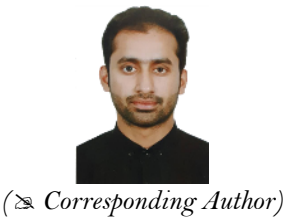

( Corresponding Author)

\begin{abstract}
This study would determine how external governance structure improves the performance of listed banks in Pakistan with the return on assets (ROA), return on equity (ROE), earnings per share (EPS) and dividend payout ratio (DPR) estimates. The study concerned external corporate governance with the presence of foreign ownership as a moderator. The sample design of the study is listed banks in Pakistan stock exchange (PSX) from 2009 to 2018 with the availability of foreign ownership data. The data are gathered from financial statements, shareholding trends, and the credit rating agencies Pakistan (PACRA). The panel data approach (fixed and random effect model) was reversed to serve a different research objective and the study goals. The results showed that the external mechanism of governance performs an important part in the transparency and efficiency of the banking sectors. The banks could also increase foreign investment if they get better external governance mechanisms. This work will help commercial banks resolve the issues and improve compliance with the corporate governance code, and devise strategies for better functioning. This research is inconsistent as none defined the governance of the external system with the moderator presence in Pakistan.
\end{abstract}

Keywords: External governance, Performance, Foreign ownership, Banking system, Pakistan.

JEL Classification: E58; G2 1; G32; G34.

Citation | Shoaib Ali; Hafiz Muhammad Naveed; Abubakar Khaliq (2020). Does an External Governance Framework Enhance the Performance of Pakistan's Banking Sectors? Foreign Ownership as Moderator. Economy, 7(2): 110-118

History:

Received: 18 September 2020

Revised: 12 October 2020

Accepted: 26 October 2090

Published: 9 November 2020

Licensed: This work is licensed under a Creative Commons

Licensed: This work is
Attribution 3.0 License (cc) E E

Publisher: Asian Online Journal Publishing Group
Acknowledgement: All authors contributed to the conception and design of the study.

Funding: This study received no specific financial support.

Competing Interests: The authors declare that they have no conflict of interests.

Transparency: The authors confirm that the manuscript is an honest, accurate, and transparent account of the study was reported; that no vital features of the study have been omitted; and that any discrepancies from the study as planned have been explained.

Ethical: This study follows all ethical practices during writing.

\section{Contents}

1. Introduction

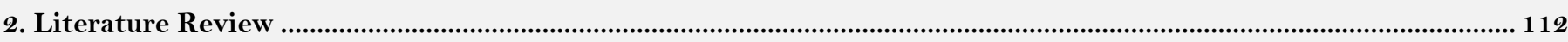

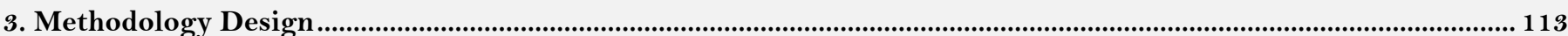

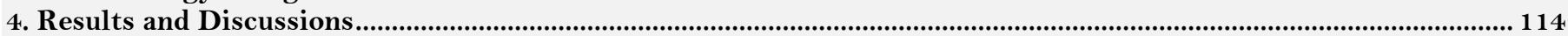

5. Conclusion

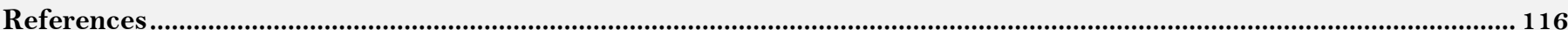




\section{Contribution of this paper to the literature}

This study contributes to existing literature by determining how external governance structure improves the performance of listed banks in Pakistan with the return on assets (ROA), return on equity (ROE), earnings per share (EPS) and dividend payout ratio (DPR) estimates.

\section{Introduction}

The organization's main goal is to figure out the issues and then seek to minimize the challenges of implementing corporate practices and mitigating misunderstandings. The poor corporate governance system and globalization of the capital markets have disrupted governance the monetary market both domestically and internationally (Sohail, Rasul, \& Fatima, 2017). In a company, the investors and consumers may be in the same place, and they could partner with multiple countries. The control board should be at the top level determined and check the efficiency of how issues can be solved because they can be detrimental to financial institutions. Several theories about (i.e. stakeholder, signaling, and resource dependency, etc.) play an important role in the establishment of a successful stockholder-management relationship.

The responsibility of stakeholder concerns that executives and organizations struggle because of personal gains and poor governance structure. Wijnberg (2000) defined a community or individual as stakeholders who may affect the success of the aims or priorities of the organization. Corporate governance has the function of offering an assurance that managers are working to boost the returns of shareholders. The theory of stakeholders is the opposite the philosophy of the agency and its manager are seen as a participant rather than an entity. Organizational performance and shareholder satisfaction are the main relationships that explain long term organizational effectiveness (Donaldson \& Davis, 1991). Another use is the resource dependency theory, which demonstrates a lack of all the institution's resources and expertise needed to achieve the desired results and achieve organizational objectives. Hence, it relies on the resources and hardships of an organization that exceeds the central agency's capacity (Reitz, 1979). The theories outlined above suggest an organizational governance framework that improves the firms' efficiency.

The Agency issues insolvency root for different organizations (i.e. WorldCom and Enron) and this purpose (such as the Blue-Ribbon Committee; the Federation for Economic Cooperation and Growth or the OECD; the Cadbury Group; the King Committee; the European Surveillance Dealers' Federation or the EASD and the Banking Supervisory Group of Basel) clarified the criteria and principles for the management of issues. Such groups aim to strengthen the corporate governance foundations for a monitoring framework to come up with corporate governance. However, deals with business management's privileges and responsibilities, the organization, and the interests of the stakeholders.

Banks are classified as intermediaries, which gather money from depositing investors, lend it, and verify on their behalf. Levine (2003) argued that heavy dependence on the banking industry is the driving force of economic growth in developing countries although Arun and Turner (2004) described, that in the underdeveloped monetary markets, banking sectors are the most-vital basis of financing for the mainstream of the organizations and core collection for the economic reserves. Hence, the worth of banking sectors in the economy and the breakdown of the banking sectors will straight disturb the monetary flow of the economy (Banerjee, 2005).

The banking institutions and external governance create an operative situation among the management, stakeholders, investors, and creditors for the sake of improving its success. In Pakistan, the system of governance code for banks was first introduced in 2003 by the State Bank of Pakistan (SBP), but subsequently, it was updated and acquired a new governance framework with improvements from 2009 to 2011. Pakistan is an emerging country and its banking industry is faced with problems including high-interest rates, equity inflows or outflow, the narrow scope of commodities, indiscriminate consumption and pledge loans, undiversified managerial budges, and union intervention in forecasting, poor decision-making, weak human means allocations, and weak external operations. The predictors and experts analyzed that the main reason for the poor performances of the firms is the lack of a comprehensive corporate governance mechanism.

The prior research was concentrated on financial or non-financial sectors to evaluate corporate governance's relationship to firm performance. This study focuses on the effect that the governance process has on the viewpoint of the banking institutions. The banking sector and the corporate governance structure are explained by the banks themselves. A wider corporate governance view should be enforced attributable to banking organizations, affecting both creditors and stakeholders (Mullineux, 2006).

The shortcomings of the governance system contribute to financial fraud and powerlessness. According to a report banking institutions with poor regulations were exhausted (Peni \& Vähämaa, 2012). This has explained that insufficient corporate governance will adversely cause problems with the economic list of a country (Sharma \& Rathi, 2014). Governance mechanisms fragile and wide-open participation in financial represent obstacles to financial market regulation at home. Financial organizations are facing many problems recently in a global environment without governance. There are still issues with the essence of banking, the regulatory process, shareholders, creditors, and forecasters.

This research intends to examine the impact of governance mechanism on the performance of listed banks in Pakistan. There are distinct codes of a governance mechanism for commercial institutions while SBP articulates in the shape of prudential regulations. This research contributes some novelty to the current literature. First of all, the data establish more expressive, comprehensive, and the target population of the study is private banks identified in PSX, the sampling technique is purposive. We have taken steps from the conventional framework of the earlier literature and, regardless of how internal governance is determined, we have used external structures to protect minority shareholders (PMS), financial transparency, external auditors, and foreign ownership as moderators.

\subsection{Objectives of the Study}

- To assess the effect of PMS on the performance of banks with the moderator of foreign ownership. 
- To identify the impact of financial transparency on the performance of banks with the moderator of foreign ownership.

- To analyze the effect of external auditors relating to bank performance with the moderator of foreign ownership.

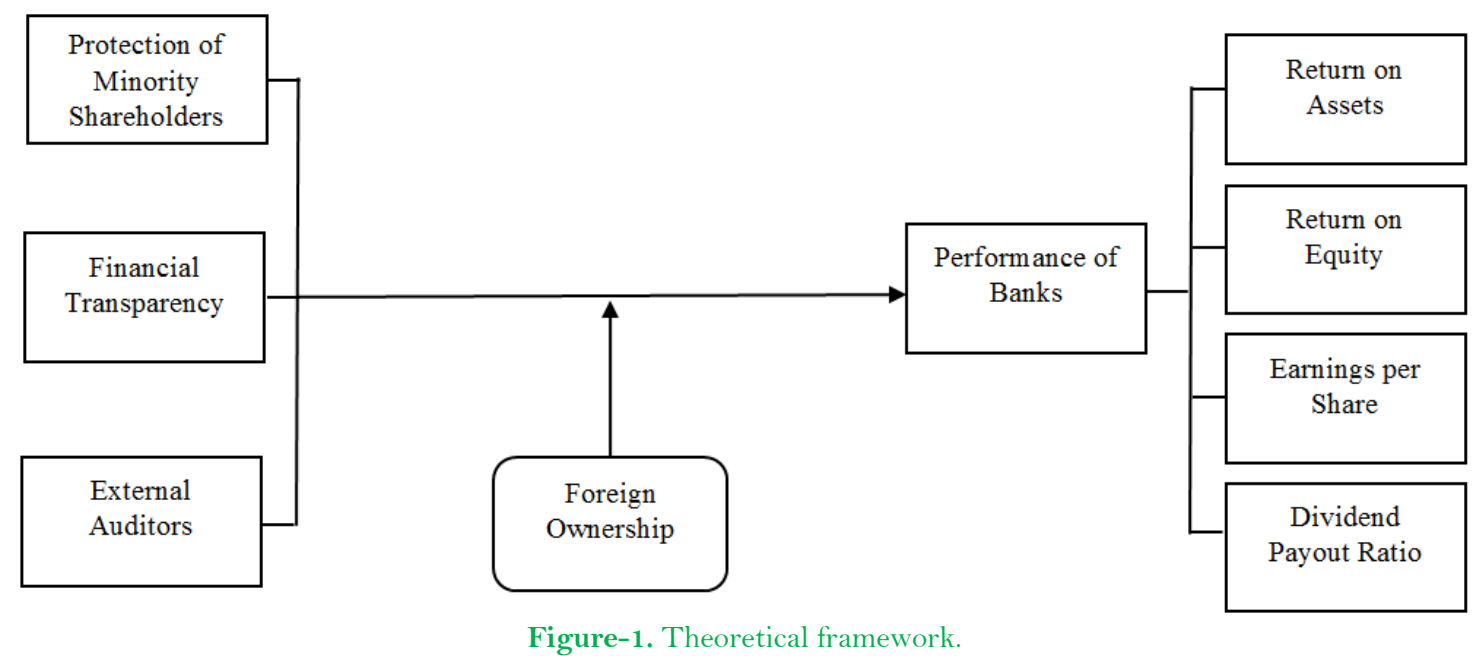

The paper is managed as follows. In unit 2 we elaborate theoretical analysis for the encouragement of external governance mechanisms and engaged empirically hypotheses to test. Unit 3 consists of a description of the target population, as well as the firms' aspects that are considered in our study. In unit 4 their results regressed explanations with a panel data approach (fixed and random effect model). Finally, unit 5 states our conclusive remarks.

\section{Literature Review}

There are significant facts concerning the value of governance mechanisms in banking institutions. The governance mechanism would be capable to decrease seize of bank reserves and encourage bank competency (Caprio, Laeven, \& Levine, 2007). The banking sectors have been contributed positively to the performance of the firms (Eldomiaty \& Choi, 2011). Banking institutions in Germany as features universal banking system are operating financing institutions in comparison with capital markets. There is a need to involve more part of the governance mechanism to maintain positions of lenders, major stakeholders, underwriters, corporate position holders, stock exchange position holders, and communicating vote rights by the minority of shares (Lowengrub, Luedecke, \& Melvin, 2004). Tulepova (2017) argued that in a circumstance of huge credit-ship where organizations depend on credit from financial sectors, banking institutions can perform governance roles by analyzing the organization's actions, annually audit, and enforce penalty payments. Thus, the comprehensive governance mechanism of banking institutions enhances the chances that banks will exceed sound governance mechanisms over other organizations.

This study analysis defines the connotation of corporate governance and the performance of banking institutions. The monetary power of an organization is closely associated with good corporate governance. Ownership structure, legal underlay with PMS, financial disclosure, and external auditors are constructive measures that have a major impact on the operations of banking firms' results.

\subsection{Protection of Minority Shareholders}

There has been the practice that conflicts of compensation occur between the shareholder minority and the majority of shareholders. This is a legal defense framework for the PMS and its stock trading on the capital markets. Corporate governance relating to investigation approvals, economic position, conditions on the capital market, independent statutory structures, managing the economy theory aspects, institutional growth, investment frameworks, and PMS testimonials (Bai, Liu, Lu, Song, \& Zhang, 2006).

There are also disputes about the relevant PMS standard. Different types of experts have different opinions when addressing PMS. Coffee and Schwartz (1981) emphasized several important points about PMS imitation procedures, such as mismanagement and harassment prevention. It also reduces the risks involved in the corporate administration of service payments. According to Fischel and Bradley (1986) concerns about the validity of criminal prosecutions are imitative about PMS. They also encouraged managers to work collectively for PMS and other firms, while many instruments for corporate governance initiatives require explicit disclosure statements from management for minority shareholder litigation. A minority of stockholder's usefulness because they do not perform the minimal level in determining the indemnity for a useful outcome. The investigators do not present an empirically valid approach to measures the weak institutional return flow as it does not yield reliable PMS behavioral results (Thompson \& Thomas, 2004).

$H 1=P M S$ positively increases the performance of the banks with foreign ownership as a moderator.

\subsection{Financial Transparency}

Public confidence is reduced from financial institutions that have a negative effect on social, economic trends which actions towards poor results (Cadbury, 2011). Procedural accountability and facts reveal critical and essential aspects of the governance process (Damodaran, 2007). Corporate governance is a set of principles for promoting transparency, honesty, morals, ethics, equity, duty, and accountability in the policies and practices of the board of directors of the company. Granof (2003) also clarified that the corporate structure fulfills the role of authority, guiding principles, participation, honesty, respect for shareholders' rights, processes, practices, governance policies, financial transparency, accuracy, and performance access results. The financial accountability 
and confidentiality of current-state data are central to corporate processes. Corporate governance codes exist, group trust with knowledge revealing is called an exchange feature to detect the institution's functioning. The prior research information presented and considered non-binding which is used to appease creditors and capital markets (Healy \& Palepu, 2001).

In addition to this, there is a negative relationship between financial transparency and organizational performance (Chen, Chung, Lee, \& Liao, 2007). On the other side, The correlation between financial transparency and organizational growth is positive (Bai et al., 2006). Organizational performance can possible to increase if it achieves a good credit rating, which enhances its fame, and more stockholders engage for investment (Lukas \& Basuki, 2014).

H2= Financial transparency positively associated with the performance of the banks with foreign ownership as moderators.

\subsection{External Auditors}

An addition to the governance mechanism is external auditors which can control administrative unrestricted activities. Watts and Zimmerman (1983) explained that on the base of stakeholder theory, an external audit decreases instruction inequality between the director and the operator and reduces conflicts of interest. Botez (2009) identified the primary function of the International Accounting Standard (IAS) for external auditing is to restore the competencies to trust users in the assessment of financial statements to preserve the accountability environment and to satisfy stakeholders. IAS will enhance control and timely auditing of financial data during IAS through banks and corporate decision-makers, and the use of processes in decision making. Afify (2009) There is confirmation that coverage and reporting rates reduce asymmetries between internal and external information and increase marketplace performance. Al-Ajmi (2008) also indicated that it is necessary to look at the possibilities and risks for negative payments during an argument and elimination of the financial market bad rumors about performance. The reducing number of tests carried out by coordinating to internal auditors, especially those concerned for external auditing that is the main function (Abbott, Parker, \& Peters, 2012).

A study has a significant effect on the internal investigators working with external auditors. It is also considered to have implications that would lead to improvements in the financial statement audit report being reviewed, which is prepared by external auditors. Timely operations conducting audit procedures and audit-related tasks. The prior research between external audit and earnings management revealed a poor relationship with external auditors and a huge risk (Becker, Defond, Jiambalvo, \& Subramanyam, 1998).

$H 3=$ External auditors positively increase the performance of the banks with foreign ownership as moderator.

\subsection{Foreign Ownership}

The ownership structure has different predictions which include foreign ownership, government ownership, ownership concentration, and managerial ownership, etc. But this research focused on foreign ownership as a moderator. Earlier studies have examined the multi-measurements ways of connection between ownership structure and performance. Institutional ownership has a significant positive association on performance (Badrul \& Shahid, 2012). The organization without managerial ownership executes less efficiency than those organizations that use more managerial ownership.

On the other side, foreign ownership plays a vital role in financial firms' performance. Also, foreign stockholder looks to choose huge cash organizations with large stocks of their reserves in large organizations (Dahlquist \& Robertsson, 2001). Bokpin (2013) argued banks that have domestic ownership are low profit-maker but as compared those banks who have foreign ownership are making huge profits. Foreign ownership has a positive relationship with financial institutions (Dahlquist \& Robertsson, 2001). The foreign investors play an efficient role in growing countries and create a leading environment (Micco, Panizza, \& Yañez, 2007). International corporations have a new framework, regulations, and standards that do not exist in the domestic market until the national banking system functions better (Bris, Brisley, \& Cabolis, 2008). They also clarified that when international investors participate, the firm's profitability and credibility improve.

\section{Methodology Design}

\subsection{Description of Data}

This research entirely focused on quantities sources from the listed banks on the Pakistan Stock Exchange (PSX), excluding foreign banks due to data unavailability. The data is collected from the State Bank of Pakistan (SBP) website, annual report of banks, the shareholders' patterns, and Pakistan Credit Rating Agency (PACRA) from 2009 to 2018. A total of 23 commercial banks was listed in PSX during the study. Thus, banks with insufficient data were removed from the study. So, the final sample of data comprised 22 listed banks with 204 firm annual observations. This research looks at the external governance structure and econometric model used for the target population in the explanatory variables.

\subsection{Structure of Variables}

We assess the external governance process with the PMS, financial transparency, and the external auditor to check the relationship on organizational performance with ROA, ROE, EPS, and DPR. In addition to this, we also measure the effectiveness of the commercial bank's performance with foreign ownership as a moderator. Two control variables as bank size and leverage are included in the regression to control the bank definite elements that may change the performance of firms. Operationalization definitions of these variables are listed in Table 1.

\subsection{Econometric Assessment}

The data in this research include banks with 204 observations from 2009 to 2018. This research was applied to the panel data approach (fixed or random effect model) for the analysis of the results. The MorckHausman (1978) test used when the model with the fixed effect is an accurate or random-effect model to an assortment of activity (Moussa \& Aymen, 2014). 
Table-1. Variable development interpretations.

\begin{tabular}{l|l|l|l}
\hline Variables names & Kind of variables & Short-form & Proxies \\
\hline Return on Assets & Dependent & ROA & $\begin{array}{l}\text { Return after tax proportion to total assets. } \\
\text { (Al-Saidi \& Al-Shammari, 2013). }\end{array}$ \\
\hline Return on Equity & Dependent & ROE & $\begin{array}{l}\text { Return after tax proportion to stockholder's } \\
\text { equity. (Badrul Muttakin \& Shahid Ullah, } \\
\text { 2012) }\end{array}$ \\
\hline Earning Per Shares & Dependent & $\begin{array}{l}\text { Return after tax proportion to numbers of } \\
\text { common stocks. (Sheikh. \& Karim, 2015) }\end{array}$ \\
\hline Dividend Payout Ratio & Dependent & $\begin{array}{l}\text { Total dividends proportion by net return. } \\
\text { (Mason, Franks, \& Broyles, 1980) }\end{array}$ \\
\hline $\begin{array}{l}\text { Protection of } \\
\text { Shareholders }\end{array}$ & Explanatory & PMS & $\begin{array}{l}\text { If the stocks are exchanged on the stock } \\
\text { market then 1, otherwise 0. (Bai et al., 2006) }\end{array}$ \\
\hline Financial Transparency & Explanatory & $\begin{array}{l}\text { Reflects score advertised } \\
\text { organizations in the market for its stable } \\
\text { financial situations. (Bai et al., 2006) }\end{array}$ \\
\hline External Auditors & FT & $\begin{array}{l}\text { Represented as if the bank is inspected by } \\
\text { the external auditor 1, otherwise 0. }\end{array}$ \\
\hline Foreign Ownership & Moderator & $\begin{array}{l}\text { Evaluated from financial statements of } \\
\text { banks (stockholder scheme). }\end{array}$ \\
\hline Bank Size & Control & EAUD & $\begin{array}{l}\text { "Ratural logarithm of the total assets". } \\
\text { (Sheikh. \& Karim, 2015) }\end{array}$ \\
\hline Leverages & Fontrol total assets" \\
\hline
\end{tabular}

\subsubsection{Unmoderated Estimates}

To analyze the above stated hypothesis, four equations are developed, which are given below: First model:

$R O A_{i t}=\alpha_{o}+\beta_{i t} P S_{i t}+\beta_{2}$ FINTR $_{i t}+\beta_{s i}$ EXAUD $_{i t}+\beta_{t} F O R O W N_{i t}+\beta_{s}$ BNKSIZ $_{i t}+\beta_{6}$ LEVGS $_{i t}+\pi_{i t}$ Second model:

$R O E_{i t}=\alpha_{o}+\beta_{i i} P M S_{i t}+\beta_{2}$ FINTR $_{i t}+\beta_{s i}$ EXAUD $_{i t}+\beta_{4}$ FOROWN $_{i t}+\beta_{5}$ BNKSIZ $_{i t}+\beta_{6}$ LEVGS $_{i t}+\pi_{i t}$

Third model:

$E P S_{i t}=\alpha_{o}+\beta_{l i} P M S_{i t}+\beta_{2} F I N T R_{i t}+\beta_{3 i} E X A U D_{i t}+\beta_{i} F O R O W N_{i t}+\beta_{j} B N K S I Z_{i t}+\beta_{6} L E V G S_{i t}+\pi_{i t}$

Fourth model:

$D P R_{i t}=\alpha_{o}+\beta_{i t} P M S_{i t}+\beta_{2} F_{I N T R}+\beta_{s i} E X A U D_{i t}+\beta_{t} F O R O W N_{i t}+\beta_{s} B_{N K S I Z}+\beta_{6} L E V G S_{i t}+\pi_{i t}$

\subsubsection{Moderated Estimates}

Four equations are developed with moderator, which are given below:

First model:

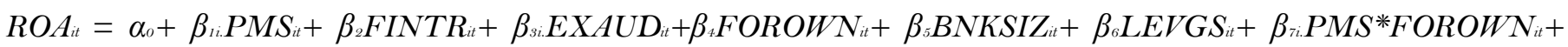
$\beta_{s}$ FINTR $^{*}$ FOROWN $_{i t}+\beta_{9 i}$ EXAUD $^{*}$ FOROWN $_{i t}+\pi_{i t}$

Second model:

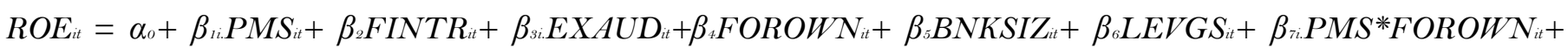
$\beta_{s}$ FINTR $^{*}$ FOROWN $\mathrm{N}_{i t}+\beta_{9 i}$ EXAUD $^{*}$ FOROWN $_{i t}+\pi_{i t}$

Third model:

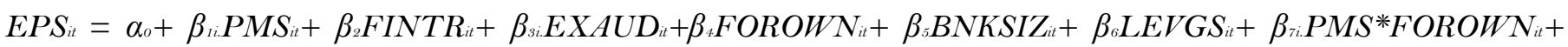
$\beta_{s}$ INTR $^{*}$ FOROWN $\mathrm{N}_{i t}+\beta_{9 i}$ EXAUD $^{*}$ FOROWN $\mathrm{N}_{i t}+\pi_{i t}$

Fourth model:

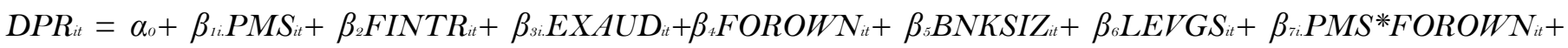
$\beta_{s}$ FINTR $^{*}$ FOROWN $_{i t}+\beta_{9 i}$ EXAUD $^{*}$ FOROWN $_{i t}+\pi_{i t}$

\section{Results and Discussions}

\subsection{Hausman Test Information}

The MorckHausman (1978) introduced differentiation both the fixed and the random-effect model. For the data analysis, a combination of time series and cross-sectional data was also used, and by applying the time series and cross-section observation, panel data identify accurate and reliable results that can add some valuable information in research. The panel data approach calculates the impact that is not observable in pure time series knowledge (Mason et al., 1980). The panel data were selected for more accurate results from the banking sector and minimizes the biases.

A conclusion that $\mathrm{P}<0.05$ as evidence that there are two models dissimilar enough to reject the null hypothesis at the conformist level of significance, there is to reject and simulate of random effects in place of a fixed-effect model. As a modal estimation, the Hausman test was employed for each experiment to decide if the fixed effect model is the correct one, or if the model is better for the random effect.

Table-2. Hausman test elucidation

\begin{tabular}{c|c|c|c|c|c}
\hline Models & Variables & Chi & P-value & Accept or Reject & Fixed or Random model \\
\hline First & ROA & 4.09 & 0.218 & HO: Accept & Random \\
\hline Second & ROE & 1.89 & 0.914 & Ho: Accept & Random \\
\hline Third & EPS & 5.1 & 0.305 & HO: Accept & Random \\
\hline Fourth & DPR & 59.14 & 0.001 & Ho: Reject & Fixed \\
\hline
\end{tabular}


According to the test standards Table 2 shows that model first, second, and third accept the null hypothesis $\left(\mathrm{H}_{0}\right)$ and the random model is applying. But on the other side, the fourth model rejects the $\mathrm{H}_{0}$ and fixed effect random effect model applies.

Table 3 showing a combined summary of statistics and correlation matrix. The mean ROA is 9.01\% and ROE is $43.12 \%$. Similarly, the mean of EPS and DPR are Rs.1.90 and 6.92 respectively. This percentage is a little high in commercial banks than other non-financial institutions and other variables are showing low percentage results as compared to Sheikh, Wang, and Khan (2013); Sheikh. and Karim (2015); Sohail et al. (2017). Besides that, the matrix of correlations showing there is no severe multicollinearity among these variables.

\subsection{Correlation Matrix and Statistics}

Table-3. Descriptive statistics and correlation matrix.

\begin{tabular}{c|c|c|c|c|c|c|c|c|c|c|c|c}
\hline Variables & Mean & SD & ROA & ROE & EPS & DPR & PMS & FT & EAUD & FOWN & BS & LEV \\
\hline ROA & 0.0901 & 0.4209 & 1 & & & & & & & & & \\
\hline ROE & 0.4312 & 0.7038 & $0.745^{* *}$ & 1 & & & & & & & \\
\hline EPS & 1.9012 & 2.0945 & $0.567^{* *}$ & $.456^{* *}$ & 1 & & & & & & & \\
\hline DPR & 6.9231 & 1.9341 & $0.614^{* *}$ & $.546^{* *}$ & $.767^{* *}$ & 1 & & & & & & \\
\hline PMS & 0.0340 & 0.2304 & $-0.317^{*}$ & $-.322^{*}$ & $-.657^{* *}$ & $-.510^{* *}$ & 1 & & & & & \\
\hline FT & 0.2035 & 0.5902 & -0.108 & -0.139 & -0.14 & $-.326^{* *}$ & -0.044 & 1 & & & & \\
\hline EAUD & 1.2091 & 0.2684 & -0.003 & -0.142 & -0.104 & -0.024 & 0.0 & -0.182 & 1 & & & \\
\hline FOWN & 0.6102 & 0.0236 & $.465^{* *}$ & $.234^{*}$ & $.276^{* *}$ & $.297^{* *}$ & $-.317^{* *}$ & $.203^{*}$ & $.331^{* *}$ & 1 & & \\
\hline BS & 8.5024 & 2.7649 & 0.191 & $.351^{* *}$ & $.268^{* *}$ & $.273^{* *}$ & 0.061 & 0.055 & $-.235^{*}$ & -0.184 & 1 & \\
\hline LEV & 2.0612 & 1.3876 & $-.341^{* *}$ & -0.063 & -0.19 & $-.305^{* *}$ & 0.065 & $.216^{*}$ & -0.057 & $-.357^{* *}$ & $.239^{*}$ & 1 \\
\hline
\end{tabular}

*Correlation is significant at the 0.01 level (2-tailed)

The results of Table 4, the First model designates that the PMS has a negative impact on ROA. It indicates that PMS does not participate to increase firm performance. This is useless to PMS because they do not play any part in putting organizational performance inducements (Thompson \& Thomas, 2004). Further, for the sake of motivation to act positively with a minority of stakeholders and other companies that may play a positive role in firm performance. The financial transparency indicates negative and insignificant measurements on ROA. Financial transparency and company results have a negative relationship (Chen et al., 2007). Financial transparency does not play a part to enhance firm performance. The external auditor shows a positive and insignificant relationship on ROA. The more external auditors reveal objection about the trustworthiness of financial information which is communicated via the financial statements of banks. A prior study between external audit and earning management showed a negative relationship and a huge risk with external auditors (Becker et al., 1998). After regressed moderation, PMS shows positive and insignificant relationship on ROA, which means the participation of foreign ownership can increase the efficiency of banking institutions.

Table-4. Effect of the external governance framework on banking sector performance.

\begin{tabular}{|c|c|c|c|c|c|c|c|c|}
\hline \multirow{2}{*}{$\begin{array}{c}\text { Variables } \\
\text { PMS }\end{array}$} & \multicolumn{2}{|c|}{$\begin{array}{c}\text { First model ROA } \\
\text { Coefficient } \\
\text { Probability }\end{array}$} & \multicolumn{2}{|c|}{$\begin{array}{c}\text { Second model ROE } \\
\text { Coefficient } \\
\text { Probability }\end{array}$} & \multicolumn{2}{|c|}{$\begin{array}{c}\text { Third model EPS } \\
\text { Coefficient } \\
\text { Probability }\end{array}$} & \multicolumn{2}{|c|}{$\begin{array}{c}\text { Fourth model DPR } \\
\text { Coefficient } \\
\text { Probability }\end{array}$} \\
\hline & $-0.505^{*}$ & 0.274 & -7.252 & 0.077 & $-7.654^{*} *$ & 0.114 & 0.000 & 0.691 \\
\hline FT & -0.013 & 0.040 & -0.951 & 0.087 & 0.150 & 0.086 & 0.273 & 0.108 \\
\hline EAUD & 0.145 & 0.215 & -2.326 & 0.024 & 0.745 & 0.063 & $-15.62^{*}$ & 0.256 \\
\hline $\mathrm{BS}$ & 0.142 & 0.103 & $3.330^{* * *}$ & 0.115 & 1.576 **** & 0.020 & -26.10 & 0.054 \\
\hline LEV & -0.026 & 0.037 & -0.336 & 0.045 & -0.083 & 0.003 & 0.457 & 0.010 \\
\hline FOWN & -0.017 & 0.034 & -0.306 & 0.282 & $0.589 * * *$ & 0.012 & -3.230 & 0.021 \\
\hline FOWNPMS & 0.002 & 0.007 & -0.021 & 0.558 & -0.033 & 0.052 & 2.506 & 0.023 \\
\hline FOWNFT & $0.001^{*}$ & 0.001 & 0.017 & 0.091 & $-0.019^{* *}$ & 0.423 & -0.003 & 0.201 \\
\hline FOWNEAUD & -0.010 & 0.026 & 0.081 & 0.129 & -0.176 & 0.231 & 3.398* & 0.432 \\
\hline Constant & 2.901 & - & 45.67 & - & 4.240 & - & 153.7 & - \\
\hline Wald chi2 & 30.41 & - & 40.74 & - & 160.2 & - & 6.41 & - \\
\hline
\end{tabular}

Financial transparency indicates positive and significant measurement on ROA, which indicates through foreign ownership financial transparency plays an important role in the advancement in banks' performance. Financial transparency is measured positively on firm performance (Bai et al., 2006). The external auditor reveals a negative and insignificant association on ROA. It shows that the participation of foreign investment and the capability of disclosing is essential to restrict banking performance. It is most valuable that an external auditor should retain his client sovereignty (Lennox, 1999).

The results of the second model indicate that PMS effects on ROE negative and insignificant. It explains considering PMS does not generate profit for the firm. Wei-qi (2010) highlighted, to produce PMS interest, the focus must be pay on disciplining a firm when it issues any material or annual report. The effect of financial transparency on ROE is negative and insignificant, that would be banks do not have enough consideration to maximize the profit. Besides this, there is one negative measurement of financial transparency on organizational efficiency (Chen et al., 2007). The external auditor has a negative insignificant measurement of ROE. Based on this result external auditors do not participate in incremental return for banks. On the other hand, external auditor has a positive relation with co-audit (Boulila Taktak \& Mbarki, 2014).

Therefore, after regressed moderation, PMS has negative insignificant relation on ROE, which shows even participation of foreign investors does not increase banks' performance. In addition to this, it is normally argued that foreign investors demand a high quality of information because of their fame (D'Souza, Nash, \& Megginson, 2005). The financial transparency has a positive insignificant impact, which shows that cooperate foreign investors 
play a significant side. So, External auditors have a positive impact and indicate that they participate in the advancement of the firm return.

The results of the third model, show that PMS has a negative and significant effect on EPS. It highlights that focusing on PMS does not improve earnings on shares. The specialists would not suggest the easy way that analyses the poor flow value of organizations as it would not offer positive outcomes for the benefit regarding PMS (Thompson \& Thomas, 2004). Whereas, financial transparency has positive and insignificant relation with EPS, which explains the credibility of banks plays a vital role to maximize the return on shares. Transparency of functioning and revelation of key information are the basic dimensions of governance mechanism (Bushman, Piotroski, \& Smith, 2004; Damodaran, 2007). The external auditor on EPS is a positive and significant effect, which reveals that it increases profit on shares effectively. So, after running moderation PMS has a negative insignificant impact on EPS, which examines that after engaging foreign investors do not enhance return on shares. Financial transparency has a negative significant role and indicates that it does not improve return on shares with foreign ownership. The external auditors have negative effects and reveals that they with foreign investors do not enhance return on shares. Therefore, the external auditors have a negative relationship with organizational efficiency (Boulila Taktak \& Mbarki, 2014).

The outcomes of the fourth model show that PMS has a positive and insignificant relation on DPR. It interprets that PMS plays an important role in the retained amount in the firm and help to pay its debts. PMS also reduces the costs of the agency fees found in the management of companies. Besides, financial transparency affects DPR positively and insignificantly, it highlights that transparency must help banks to pay off their outstanding. Financial transparency has a positive connection with the success of organizations (Bai et al., 2006). The external auditor has negative and significant relation on DPR, it means that it does not help to firm for reserve. Sometimes it causes an imbalance between firms and external audit firms (Bennecib, 2004).

While regressed moderation, PMS has positive and insignificant relation on DPR which examines that foreign investors are more vigilant in observing activities than with domestic investors (Ferreira \& Matos, 2008). Aggarwal, Erel, Ferreira, and Matos (2011) examined that foreign investors also play a valuable role in enhancing governance mechanisms, particularly in countries with the protection of weak stakeholders. The financial transparency has a negative impact and shows that it does not take part in retained firm debt even with foreign investors. The information provided is deemed non-binding and can be used to accommodate the financial system and investment firms (Healy \& Palepu, 2001). The external auditors have positive significant relation and they paid the efficient debt of the firm with the engagement of foreign investors. External auditors are another governance mechanism that restrains administrators' non-compulsory activities.

In brief, the positive and negative impact of explanatory variables before and after moderation on banking performance shows that instead of weak governance mechanism in-country external governance seems to have a worthwhile impact on the performance of banks. Aggarwal et al. (2011) explained that foreign stakeholders also play an effective role in the activities of upgrading governance structures, especially in countries with weak governance practices.

\section{Conclusion}

The study analyzed the effect of the external governance structure on the commercial bank's performance in Pakistan. The panel technique has regressed as the sample design includes 23 listed banks in PSX from 2009-2018. The study examined four models to inspect the relationship of external mechanisms on banking sectors. This research intended to investigate the components of governance mechanism that source to upgrade the efficiency of banking institutions. The findings investigated that PMS does not play a considerable part in the performance even with foreign ownership (Anderson, Chi, \& Liao, 2019; Shan, 2013; Thompson \& Thomas, 2004). The foreign stakeholders also play an effective role in the advancement of governance mechanism activities, especially in those countries that have weak governance practices Aggarwal et al. (2011). The financial transparency direct and moderation shows the same results which enhance the improvement of the performance of banks (Bai et al., 2006; Chen et al., 2007). Furthermore, the external auditors show mixed results in four models which is to retrieve user confidence in the financial statement the transparency ecosystem should be maintained, and stakeholders satisfied (Botez, 2009). In sum, it comes up with the motivation to supervise performance practices in banking sectors. Although the external auditor's ability to show reservations has obstructive effects on the manager's tact.

In addition to this, results indicate that instead of weak governance mechanism there is still governance measures considerably affect the bank performance in Pakistan. Bank administrators, depositors, prospect shareowners, should consider the value of these measures although making forecasting or decisions.

Furthermore, legislative authorities should follow some important measures to apply regulations for productive governance mechanisms in the country. We have explained the impact of some external governance analyses regarding the performance of banks listed in the PSX. So, there is still a need to examines the impact of some other governance variables like separation of CEO, committee designs, rights, and responsibility of shareholders on the profit of banking sectors. The external governance can also check by including international banks that are working in Pakistan but not included in this study due to data unavailability.

\section{References}

Abbott, L. J., Parker, S., \& Peters, G. F. (2012). Internal audit assistance and external audit timeliness. Auditing, 31(4), 3-20. Available at: https://doi.org/10.2308/ajpt-10296.

Afify, H. A. E. (2009). Determinants of audit report lag: Does implementing corporate governance have any impact? Empirical evidence from Egypt. Journal of Applied Accounting Research, 10(1), 56-86. Available at: https://doi.org/10.1 108/09675420910963397.

Aggarwal, R., Erel, I., Ferreira, M., \& Matos, P. (2011). Does governance travel around the world? Evidence from institutional investors. Journal of Financial Economics, $100(1), 154-181$. Available at: https://doi.org/10.1016/j.jfineco.2010.10.018.

Al-Ajmi, J. (2008). Audit and reporting delays: Evidence from an emerging market. Advances in Accounting, 24(2), 217-226. Available at: https://doi.org/10.1016/j.adiac.2008.08.002.

Al-Saidi, M., \& Al-Shammari, B. (2013). Board composition and bank performance in Kuwait: an empirical study. Managerial Auditing Journal, 28(6), 472-494. Available at: 10.1108/02686901311329883. 
Anderson, H., Chi, J., \& Liao, J. (2019). Foreign strategic ownership and minority shareholder protection. Emerging Markets Review, 39, 3449. Available at: https://doi.org/10.1016/j.ememar.2019.03.005.

Arun, T. G., \& Turner, J. D. (2004). Corporate governance of banks in developing economies: Concepts and issues. Corporate Governance: An International Review, 12(3), 371-377. Available at: https://doi.org/10.1111/j.1467-8683.2004.00378.x.

Badrul, M. M., \& Shahid, U. M. (2012). Corporate governance and bank performance: Evidence from Bangladesh. Corporate Board: Role, Duties and Composition, 8(1), 62-68. Available at: https://doi.org/10.22495/cbv8i1 art5.

Badrul Muttakin, M., \& Shahid Ullah, M. (2012). Corporate governance and bank performance: Evidence from Bangladesh. Corporate Board: Role, Duties and Composition, 8(1), 62-68. Available at: 10.22495/cbv8i1art5.

Bai, C. E., Liu, Q., Lu, J., Song, F. M., \& Zhang, J. (2006). An empirical study on corporate governance and market valuation in China. Frontiers of Economics in China, 1(1), 83-111. Available at: https://doi.org/10.1016/j.resp.2005.07.001.

Banerjee, A. (2005). Corporate governance: A relook into the Indian banking system. SSRN Electronic Journal. Available at: https://doi.org/10.2139/ssrn.631681.

Becker, C. L., Defond, M. L., Jiambalvo, J., \& Subramanyam, K. R. (1998). The effect of audit quality on earnings management. Contemporary Accounting Research, 15(1), 1-24. Available at: https://doi.org/10.1111/j.1911-3846.1998.tbo0547.x.

Bennecib, F. (2004). De l'efficacité du co-commissariat aux comptes. Retrieved from: https://halshs.archives-ouvertes.fr/halshs-00170879.

Bokpin, G. A. (2013). Corporate disclosure, transparency and stock liquidity: Empirical estimation from the Ghana Stock Exchange. African Journal of Business Management, 7(22), 2 143-2150. Available at: https://doi.org/10.5897/AJBM 12.762.

Botez, D. (2009). Recently aspects regarding International Auditing Standard 200 Overall Objectives of the Independent Auditor and the Conduct of an Audit in Accordance with International Standards on Auditing. Studies and Scientific Researches. Economics Edition(14). Available at: 10.29358/sceco.voi14.26.

Boulila Taktak, N., \& Mbarki, I. (2014). Board characteristics, external auditing quality and earnings management. Journal of Accounting in Emerging Economies, 4(1), 79-96. Available at: https://doi.org/10.1108/jaee-10-2011-0046.

Bris, A., Brisley, N., \& Cabolis, C. (2008). Adopting better corporate governance: Evidence from cross-border mergers. Journal of Corporate Finance, 14(3), 224-240. Available at: https://doi.org/10.1016/j.jcorpfin.2008.03.005.

Bushman, R. M., Piotroski, J. D., \& Smith, A. J. (2004). What determines corporate transparency? In Journal of Accounting Research, 42(2), 207-252. Available at: https://doi.org/10.1111/j.1475-679X.2004.00136.x.

Cadbury, A. (2011). Corporate governance and chairmanship a personal view. In Corporate Governance and Chairmanship A Personal View. Available at: 10.1093/acprof:oso/9780199252008.001.0001.

Caprio, G., Laeven, L., \& Levine, R. (2007). Governance and bank valuation. Journal of Financial Intermediation, 16(4), 584-617. Available at: https://doi.org/10.1016/j.jfi.2006.10.003.

Chen, W. P., Chung, H., Lee, C., \& Liao, W. L. (2007). Corporate governance and equity liquidity: Analysis of S\&P transparency and disclosure rankings. Corporate Governance: An International Review, 15(4), 644-660. Available at: https://doi.org/10.1111/j.14678683.2007.00594.x.

Coffee, J. C., \& Schwartz, D. E. (1981). The survival of the derivative suit: An evaluation and a proposal for legislative reform. Columbia Law Review, 81(2), 261-336. Available at: https://doi.org/10.2307/1122149.

D'Souza, J., Nash, R. C., \& Megginson, W. L. (2005). Determinants of performance improvements in privatized firms: The role of restructuring and corporate governance SSRN Electronic Journal. Available at: https://doi.org/11. 747-766. 10.1016.

Dahlquist, M., \& Robertsson, G. (2001). Direct foreign ownership, institutional investors, and firm characteristics. Journal of Financial Economics, 59(3), 413-440. Available at: https://doi.org/10.1016/So304-405X(00)00092-1.

Damodaran, A. (2007). Information transparency and valuation: Can you value what you cannot see? Managerial Finance, 33(1), 877-892. Available at: https://doi.org/10.1108/03074350710823836.

Donaldson, L., \& Davis, J. H. (1991). Stewardship theory or agency theory: CEO governance and shareholder returns. Australian Journal of Management, 16(1), 49-64. Available at: https://doi.org/10.1177/031289629101600103.

Eldomiaty, T. I., \& Choi, C. J. (2011). Banks' orientation and performance in stakeholders-shareholders business systems. SSRN Electronic Journal. Available at: https://doi.org/10.2139/ssrn.462600.

Ferreira, M. A., \& Matos, P. (2008). The colors of investors' money: The role of institutional investors around the world. Journal of Financial Economics, 88(3), 499-533. Available at: https://doi.org/10.1016/j.jfineco.2007.07.003.

Fischel, D. R., \& Bradley, M. (1986). The role of liability rules and the derivative suit in corporate law: A theoretical and empirical analysis. Cornell Law Review, 7 1(2), 261-297. Available at: https://scholarship.law.cornell.edu/clr/vol7 1/iss2/2.

Granof, M. H. (2003). Building public trust, the future of corporate reporting. The International Journal of Accounting, 38(3), 391-394. Available at: https://doi.org/10.1016/s0020-7063(03)00050-5.

Healy, P. M., \& Palepu, K. G. (2001). Information asymmetry, corporate disclosure, and the capital markets: A review of the empirical disclosure literature. Journal of Accounting and Economics, 31(1-3), 405-440. Available at: https://doi.org/10.1016/So1654101(01)00018-0.

Lennox, C. S. (1999). Audit quality and auditor size: An evaluation of reputation and deep pockets hypotheses. Journal of Business Finance and Accounting, 26(7-8), 779-805. Available at: https://doi.org/10.1111/1468-5957.00275.

Levine, R. (2003). The corporate governance of banks: A concise discussion of concepts and evidence. Global Corporate Governance Forum, 3 , 1-21. Available at: https://doi.org/10.1596/1813-9450-3404.

Lowengrub, P., Luedecke, T., \& Melvin, M. (2004). Does corporate governance matter in the market response to merger announcements? Evidence from the U.S. and Germany. Advances in Financial Economics, 9, 103-135. Available at: https: 9. 103-135. 10.1016/S15693732(04)09005-X

Lukas, S., \& Basuki. (2014). The implementation of good corporate governance and its impact on the financial performance of banking industry listed in $i d x$. Paper presented at the 17th National Accounting Symposium Mataram, Lombok.

Mason, W., Franks, J. R., \& Broyles, J. E. (1980). Modern managerial finance. The Journal of the Operational Research Society, $31(1)$, 86. Available at: https://doi.org/10.2307/3009346.

Micco, A., Panizza, U., \& Yañez, M. (2007). Bank ownership and performance. Does politics matter? Journal of Banking and Finance, 31 (1), 219-241. Available at: https://doi.org/10.1016/j.jbankfin.2006.02.007.

Moussa, B., \& Aymen, M. (2014). Impact of ownership structure on financial performance of banks: Case of Tunisia. Journal of Applied Finance and Banking, 4(2), 163-182.

Mullineux, A. (2006). The corporate governance of banks. Journal of Financial Regulation and Compliance, 14(4), 375-382. Available at: https://doi.org/10.1108/13581980610711144.

Peni, E., \& Vähämaa, S. (2012). Did good corporate governance improve bank performance during the financial crisis? Journal of Financial Services Research, 41(1-2), 19-35. Available at: https://doi.org/10.1007/s 10693-011-0108-9.

Reitz, H. J. (1979). The external control of organizations: A resource dependence perspective. Academy of Management Review, 4(2), 309-310. Available at: https://doi.org/10.5465/amr.1979.4289039.

Shan, Y. G. (2013). Can internal governance mechanisms prevent asset appropriation? Examination of type I tunneling in China. Corporate Governance: An International Review, 21(3), 225-241. Available at: https://doi.org/10.1111/corg.12022.

Sharma, N., \& Rathi, S. P. (2014). Corporate governance: Conceptualization in Indian context. International Journal of Management and Social Sciences Research Explore International Research Journal Consortium, 3(5), 2319-4421.

Sheikh, N. A., Wang, Z., \& Khan, S. (2013). The impact of internal attributes of corporate governance on firm performance: Evidence from pakistan. International Journal of Commerce and Management, 23(1), 38-55. Available at: https://doi.org/10.1108/10569211311301420.

Sheikh., N. A., \& Karim, S. (2015). Effects of internal governance indicators on performance of commercial banks in Pakistan. Pakistan Journal of Social Sciences (PJSS), 35(1), 77-90.

Sohail, S., Rasul, F., \& Fatima, U. (2017). Is internal and external mechanism of governance enriching the performance of the banking sector of Pakistan? Corporate Governance (Bingley), 17(4), 629-642. Available at: https://doi.org/10.1108/CG-05-2016-0116. 
Thompson, R. B., \& Thomas, R. S. (2004). The public and private faces of derivative lawsuits. Vanderbilt Law Review, 57(5), 1747-1793.

Tulepova, I. (2017). The impact of ownership structure on CEO competition. Evidence from UK. Retrieved from: https://www.semanticscholar.org/paper/The-Impact-of-Ownership-Structure-on-CEO

Evidence/c25351d4d6be8db075415bf58ef7a680959d59e7?p2df.

Watts, R. L., \& Zimmerman, J. L. (1983). Agency problems, auditing, and the theory of the firm: Some evidence. The Journal of Law and Economics, 26(3), 613-633. Available at: https://doi.org/10.1086/467051.

Wei-qi, C. (2010). Protection of minority shareholders after the new company law: 26 case studies. International Journal of Law and Management, 52(4), 283-308. Available at: https://doi.org/10.1108/17542431011059340.

Wijnberg, N. M. (2000). Normative stakeholder theory and aristotle: The link between ethics and politics. Journal of Business Ethics, 25(4), 329-342. Available at: https://doi.org/10.1023/A:1006086226794. 